STUDIES IN ENGLISH LITERATURE

Volume 105 



\section{SHAKESPEARE AND THE USES OF IDEOLOGY}

by

SIDNEY SHANKER

Associate Professor

Queensborough Community College

City University of New York

1975

MOUTON

THE HAGUE - PARIS 


\author{
(C) Copyright 1975 in The Netherlands \\ Mouton \& Co. N.V., Publishers, The Hague
}

No part of this book may be translated or reproduced in any form, by print, photoprint, microfilm, or any other means, without written permission from the publishers

ISBN 9027931410

Printed in Belgium by N.I.C.I. Printers, Ghent 
FOR SUE 
